\title{
Factors Affecting Hot Pepper Production: The Case of Gursum District, Oromia Regional State, Ethiopia
}

\author{
Ibsa Aliyi Usmane \\ Oromia Agricultural Research Institute, Finfine, Ethiopia
}

\begin{abstract}
Hot pepper is one of the vegetable crops which serves as spices, vegetables, cash crop and ensures food security as a result of its income generating crop. But this crop is devastating by different factors which reduce its production and quality. Therefore, this study intended to undertake factors affecting hot pepper production in Gursum district with the objectives of identifying factors affecting hot pepper production, and analyze linkages of its production with the household's expenditures. The study used 150 households as sample respondents and collected primary data from them and secondary data from secondary sources, then analyzed data by mean, percentage and frequency. As a result, the finding shows that the factor affect the production of hot pepper are low price, second disease, lack of improved seed, lack of pesticide, knowledge management, lack of market access, lack of land and others like bird attack respectively. Moreover, the finding linked hot pepper production with household expenditures and found household expenses their income from hot pepper on purchasing grain, school fees, clothing, health care, festivities and others like dowry respectively. Therefore, the government and other stakeholder should focus on negotiating the market price of hot pepper and other factors hindering hot pepper production.
\end{abstract}

Keywords: Hot pepper, Gursum, cash crop

DOI: $10.7176 / F S Q M / 87-04$

Publication date:May $31^{\text {st }} 2019$

\section{Introduction}

Hot pepper (Capsicum annuum L.) is the world's most important vegetable after tomato and used as fresh, dried or processed products, as vegetables and spices or condiments (Acquaah, 2004). This crop is prominent cash crop for many developing countries' farmers such as Ethiopia, Nigeria, Ghana, China, India, Pakistan, Bhutan, Indonesia, Cambodia and Thailand (Shih-wen et al., 2013). It also lowers high blood pressure (Guarini et al., 2012); (Mustafa, 2017) and increase peripheral circulation and most popular dishes in Ethiopian cuisine (MoA, 2009). Its importance is not only limited on consumption point of view but also very prominent to farmers by generating income, creating employment opportunity and ensuring food security. This enhances profitability of those who engaged in the production of pepper. According to (Mohammed et al., 2015) research indicated that investment in hot pepper production and other vegetables (Amsalu et al., 2015) is viable enterprise for income generation, poverty alleviation, job creation and improvement of food security to every household.

Hot pepper is produced in many parts of the country. It is the main part of the daily diet of most Ethiopian societies. The fine powdered pungent product is an indispensable flavoring and coloring ingredient in the common traditional sauce "Wot", whereas the green pod is consumed as a vegetable with other food items. The average daily consumption of hot pepper by Ethiopian adult is estimated $15 \mathrm{~g}$, which is higher than tomatoes and most other vegetables (MARC, 2004). Because of its wide use in Ethiopian diet, the hot pepper is an important traditional crop mainly valued for its pungency and color.

Hot pepper has been cultivated in Ethiopia for long period of time. It is the leading vegetable crop produced in the country. Green and red hot pepper covered $3.82 \%$ and $67.53 \%$ respectively of the total estimated area under vegetables in the country. Similarly, the national production of green and red hot pepper was 412,503.57 and 2,541,883.97 quintals with average productivity of 66.88 and 23.31qt per hectare respectively (CSA, 2014). However, the agricultural extension service, and marketing focus on this crop by governments, NGOs and other stakeholders is very low. Therefore, giving focus for solving these problems come up with improvement of the production and productivity of hot pepper to ensure contributions of hot pepper to household food security in enhancing their purchasing capacity of food grain crops undertaking this study is important.

\section{Research Methodology}

The study was conducted in Gursum district, East Hararghe Zone Oromia Regional State. The information discussed in this session included the characteristics of the study area where the research was conducted and the methodology implemented by researcher.

\subsection{Sampling techniques and sample size determination}

This study used multi-stage sampling technique in which both purposive and random sampling techniques were applied. At the first stage, out of 20 districts of East Hararghe zone, Gursum district was selected purposively 
based on the potential production of hot pepper and the researcher's knowledge of the area. In the second stage, out of the total of 39 kebeles with administrations of the district, 8 kebeles were randomly selected because they were relatively with more potential hot pepper producers than other kebeles producing hot pepper. From these 8 kebeles two representative kebeles were selected purposively. In the third stage, the households in the two kebeles were categorized into two strata, i.e., hot pepper producers and non-hot pepper producers and comprehensive list of both households was prepared. Then, 150 sample households, 75 from non-hot pepper producers and 75 hot pepper producers were selected. This sample size was determined by Yemane formula (1967) in drawing an adequate sample size from a given population at 95\% confidence level, 0.5 degrees of variability and $8 \%$ level of precision in which the total of 150 sample household included from the comprehensive list of population size (4000).

$$
\mathbf{n}=\frac{\mathbf{N}}{\mathbf{1}+\mathbf{N}(\mathbf{e})^{2}}
$$

Where, $\mathrm{n}=$ sample size, $\mathrm{N}=$ total comprehensive list of population, $\mathrm{e}=$ level of precision.

$$
\mathbf{n}=\frac{4000}{1+4000(0.08)^{2}}=150
$$

\subsection{Methods of data collection, data type and source}

To generate information at household level, household level survey was undertaken using structured interview schedule. Prior to conducting the interview, pre-test of the interview schedule was undertaken in selected two kebeles with 30 respondents 15 from hot pepper producers and 15 from non-hot pepper producers and accordingly revision made and finalized. Five enumerators were recruited based on their proficiency in communicating using Afan Oromo language, educational background, and prior exposure to similar work. Training was given to enumerators on the content of the interview schedule and procedures followed in the process of conducting the interview.

The three focus group discussion were held: first with 10 producers and 10 non-producers of hot pepper (on the reasons of not participating in the hot pepper) those who were active in giving information in order to generate information on overall management aspect of the product and in the mean-time site observation and storing system of the product was made to make a note on the way the farmers handling the products. In addition, discussion was also held with non-hot pepper producers, community representative: one man and one woman, and two kebele leaders to gather further information. Furthermore, review of documents from different offices was also carried out for secondary data.

\subsection{Methods of Data Analysis}

After the completion of data collection, coding and entering the data into SPSS version 20 software and Stata version 11 were used for the analysis. Descriptive statistics like mean, frequency distribution, and percentage were used to analyze the collected data.

\section{Result and Discussion}

\subsection{Constraints of Hot Pepper Production in Study Area}

There are a number of factors affect the hot pepper production in the study area. Among these factors lack of extension services, diseases, lack of improved seeds, low market prices, lack of access to the market center and others like bird attack.

Low price of hot pepper production: the good price of any agricultural products helps farmers to capacitate in purchasing power, initiate the farmers to diversify their production, as a result, improve their livelihood and food security. In the study area farmers produce cash crops such as hot pepper, groundnut, chat and coffee. Among these cash crops that this research focused was hot pepper contribution in food security status of the household both in income generating, exchange with other grain crops, and consume it with the other food items. Even if this crop has this much contribution in food security it is affecting by different factors among which low price of the production discourages farmers to vast cultivation of hot pepper production. In the study area farmers ranked that low price of hot pepper production is one of the discouraging factors as top.

Diseases: disease is another factor which devastates the production of hot pepper in the study area in which farmers ranked it as second challenge next to price. During the survey period the farmers informed by identification of the disease's character and the solution for it, but they could not control the disease, for example, root disease, leave and fruits (pod) attack; and they recommended that as they need immediate solution disease problems

Lack of improved variety: now a day lack of improved basic seed of agricultural crops with its quality is very challenging problems farmers facing among which hot pepper are the one that still only five to six varieties reached small number of farmers in the country in general and particularly no in Gursum district. As farmers 
suggested that they had been using the hot pepper seed as early as starting agricultural activities means that there were no access of improved hot pepper variety in their kebele as a result, their hot pepper production reducing and attaching by different diseases.

Lack of pesticide: pesticide is one of the anti-biotic chemical uses to kill the pest affect production of different crops. The farmers responded that there are insects look like worms devastating the production of pepper since they could not control some disease thus, it is important to access with pesticide is necessarily an option for them to control some insect and farmers ranked it as fourth challenging factors, but they could not access to this pesticide this finding agrees with (Berhane et al., 2016).

Knowledge management of hot pepper: farmers had been producing hot pepper according to their indigenous practices for many years starting from land preparation and nursery establishment to storing the products. As they responded that they have losing their production before and after harvest due to lack of some technologies, in time of nursery preparation and storing systems, for example, as we can see from the picture they store their products on floor which expose the products to different insects and predators like rats and training and capacity building on hot pepper for farmers in study area is very low.

Low market access: market is one of the institutional game and a place where farmers exchange their agricultural products. In the study area access to market is one of the challenging factors discouraging farmers which make them not to take to market place and they ranked sixth, even large market like Harar, Jijiga and Hargeisa are there, but, farmers could not get direct contact with users rather they looting by brokers.

Land: land size in Hararghe is very low as compare to other parts of the country in general zone in particular. Even if land can be resolved as other problems, using the existing much of land effectively and in efficient way is indispensable, therefore, teaching farmers in diversifying their agricultural products and access them with reasonable price for their products is important.

Bird attack: is when birds consume their fruits/pods/ of the hot pepper at both green and maturity, the time of bird attack on the hot pepper as their response is that when other crops like maize and sorghum are not reached maturity stage. The farmers ranked this problem eighth because it is not that much challenging factor as compare to other factors.

Post-harvest loss: Most of the times in rural areas farmers store their agricultural products in traditional ways which expose their products to different insects and other damager factors. For example as it can be seen from picture captured during the survey time the storing system of the hot pepper production is very low and expose the products of hot pepper that affect the quality of it and reduce price as a result, affect food security of household.

Table 1: Constraints hot pepper production in study area

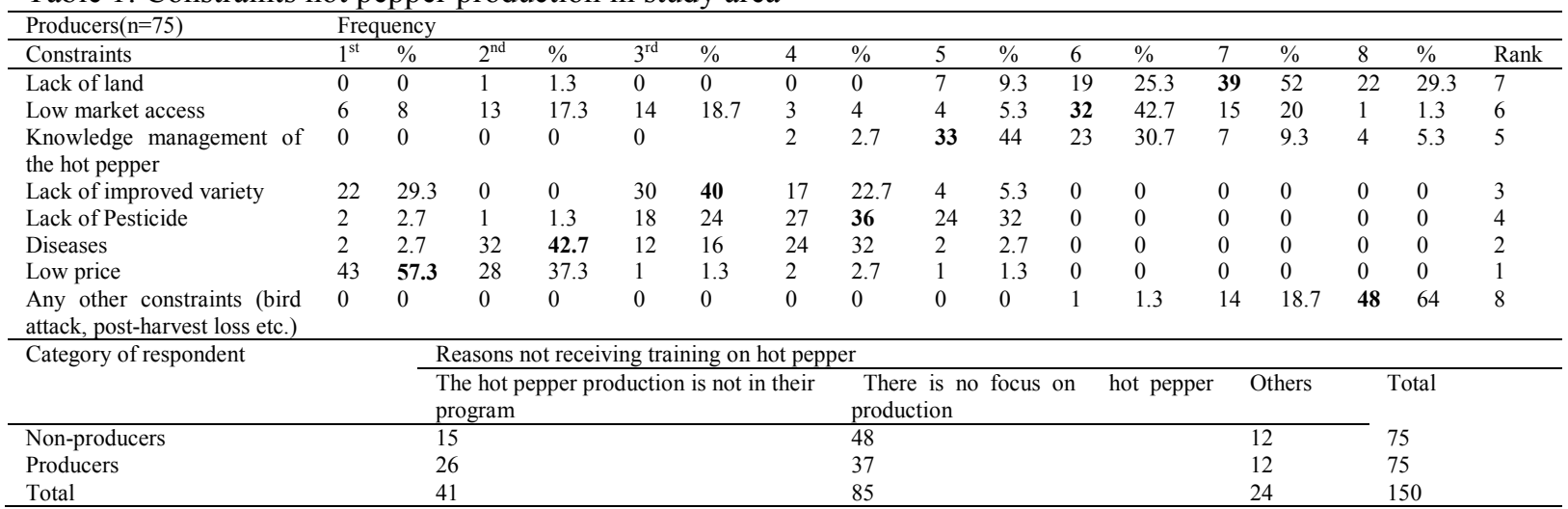

Source: own survey, 2018

\subsection{Linkages of hot pepper production to the household food security}

It is known that hot pepper is the multi-dimensional crops as other crops named as cash crops, industrial crops, vegetable, and spices. But for this research purpose and context of the study area it was selected as vegetable, and cash crops which earns more income for household and helps them to purchase grain crops in time of food shortage and even helps to purchase other food items like salt, tomato, carrot and others and no-food items such as school fees, health care and the like. As indicated in the table 6 for what purpose hot pepper producers had been expensing the income from hot pepper they pointed purchasing grain crops on first rank among other items. This means that in place of selling their milking cows, ploughing oxen and renting productive land to purchase the following food and no-food items hot pepper producers save these assets in expense of income earned from pepper. 
Table 2: Purpose of selling hot pepper

\begin{tabular}{|c|c|c|c|c|c|c|c|c|c|c|c|c|c|}
\hline \multirow{2}{*}{$\begin{array}{l}\text { Producers }(\mathrm{n}=75) \\
\text { Items }\end{array}$} & \multicolumn{13}{|c|}{ Frequency } \\
\hline & $1^{\text {st }}$ & $\%$ & $2^{\text {nd }}$ & $\%$ & $3^{\text {rd }}$ & $\%$ & $4^{\text {th }}$ & $\%$ & $5^{\text {th }}$ & $\%$ & $6^{\text {th }}$ & $\%$ & Rank \\
\hline School fee and related costs & 5 & 6.7 & 55 & 73.3 & 7 & 9.3 & 8 & 10.7 & 0 & 0 & 0 & 100 & 2 \\
\hline $\begin{array}{l}\text { Purchasing grain crops and } \\
\text { other }\end{array}$ & 60 & 80 & 13 & 17.3 & 2 & 2.7 & 0 & 0 & 0 & 0 & 0 & 100 & 1 \\
\hline Festivities & 0 & 0 & 0 & 0 & 2 & 2.7 & 2 & 2.7 & 71 & 94.7 & 0 & 100 & 5 \\
\hline Health Care & 9 & 12 & 3 & 4 & 4 & 5.3 & 58 & 77.3 & 1 & 1.3 & 0 & 100 & 4 \\
\hline Clothing & 1 & 1.3 . & 4 & 5.3 & 61 & 81.3 & 7 & 9.3 & 2 & 2.7 & 0 & 100 & 3 \\
\hline $\begin{array}{l}\text { Others (building, gift, dowry } \\
\text { etc.) }\end{array}$ & 0 & 0 & 0 & 0 & 0 & 0 & 0 & 0 & 1 & 1.3 & 75 & 100 & 6 \\
\hline \multicolumn{14}{|c|}{ Annual income obtained from hot pepper producing } \\
\hline Producers $(n=75)$ & & \multirow{2}{*}{\multicolumn{4}{|c|}{$\begin{array}{l}\text { Standard deviation } \\
6274.38\end{array}$}} & \multicolumn{3}{|c|}{ Maximum } & & \multicolumn{3}{|c|}{ Minimum } & \\
\hline Annual income & & & & & & & 00 & & & 900 & & & \\
\hline
\end{tabular}

Source: own survey, 2018

\section{Conclusion and Recommendations}

The study conducted on factors affecting hot pepper production in Gursum district and found that low price of hot pepper production in market, diseases at root, on leave of the pepper, lack of improved seed(varieties), lack of pesticide, knowledge management of hot pepper production, low market access, and land respectively. Moreover, the finding shows that the income from hot pepper selling expense on the purchasing of grains, school fees, clothing, health care, festivities, and other like dowry. Therefore, government, Non-government Organization and other relevant stakeholders should focus on hot pepper marketing, providing the improved seed/varieties and pesticide is very important.

\section{Acknowledgment}

I will thanks farmers in Gursum district for giving response in data collection.

\section{References}

Acquaah, G. (2004). Horticulture: Principles and Practices. 2nd edition. Prentice Hall of India Private Ltd. New Delhi, India. p.787

Amsalu Ayana, Tesfaye Belemi, Milkessa Temegen, Bezabih Emana, Victor Afari Sefa, Fikadu F. Dinsa. 2015. Characterization and Assessment of Vegetable Production and Marketing Systems in the Humid Tropics of Ethiopia: Quarterly Journal of International Agriculture 54 (2015), No. 2: 163-187

Guarini G, Ohanyan VA, Kmetz JG, DelloStritto DJ, Thoppil RJ, Thodeti CK, et al. Disruption of TRPV1mediated coupling of coronary blood flow to cardiac metabolism in diabetic mice: role of nitric oxide and BK channels: American journal of physiology Heart and circulatory physiology. 2012; 303(2):H216-23 doi: 10.1152/ajpheart.00011.2012

Berhane Sibhatu, Guesh Tekle and Melesse Harfe. 2016. Hot pepper varietal evaluation for growth, dry pod yield and yield related parameters at Kolla-Tembien District, Northern Ethiopia: Research Journal of Agriculture and Environmental Management Vol. 5(4), pp. 126-131, May, 2016 Available online at http://www.apexjournal.org ISSN 2315-8719

CSA (Central Statistics Agency) .2014. Report on Area and Production of Major Crops (Private Peasant Holdings, Meher Season): Agricultural Sample Survey. Central Statistics Agency, Addis Ababa, Ethiopia

Shih-wen Lin, Yu-yu Chou, Hsueh-ching Shieh, Andreas W., Ebert, Sanjeet Kumar, Ravza Mavlyanova, Albert Rouamba, Abdou Tenkouano, Victor Afari-Sefa and Paul A. Gniffke. 2013. Pepper (Capsicum spp.) Germplasm Dissemination by AVRDC - The World Vegetable Center: an Overview and Introspection. Chronica Horticulture. 53(3):21-27

Melkasa Agricultural Research Center (2004). Progress Report, Addis Ababa, Ethiopia

Mohammed B., Abdulsalam Z. and Ahmed B. 2015. Profitability in Chilli Pepper Production in Kaduna State, Nigeria. British Journal of Applied Science and Technology. 12(3): 1-9

MoA (2009). Ministry of agriculture and rural development. Animal and plant health regulatory directorate. MoA, Addis Ababa, Ethiopia 